\title{
PENGARUH BAHAN KEMASAN DAN WAKTU PENYIMPANAN BAHAN STEK TERHADAP PERSENTASE BERAKAR STEK SHOREA JOHORENSIS DAN S. SMITHIANA
}

\author{
Effect of Package Material and Storage Time of Cutting Material to Rooting Percentage \\ of Shorea johorensis dan S. smithiana cuttings \\ Burhanuddin Adman \\ Balai Penelitian dan Pengembangan Teknologi Perbenihan Samboja \\ Jl. Soekarno - Hatta Km. 38, Samboja Po. Box 319 Balikpapan, Kalimantan Timur 76103 \\ Telp. (0542) 7217663 Fax. (0542) 7217665
}

Naskah masuk : 10 Mei 2010; Naskah diterima : 21 Pebruari 2011.

\begin{abstract}
The study of effect of package material and storage time to rooting percentage two kind of meranti (Shorea johorensis and S. smithiana) was conducted at greenhouse of Balai Penelitian Teknologi Perbenihan Samboja, East Kalimantan. Cutting materials of Shorea johorensis and S. smithiana was taking from wildlings at IUPHHK PT Dasa Intiga, Central Kalimantan. The objective of this study is to get the appropriate package material and effect of storage time in point to rooting percentage of $\mathrm{S}$. johorensis and $\mathrm{S}$. Smithiana. Treatments consist of three pack types $(P 1=$ hardboard, $P 2=$ styrofoam box, $P 3=$ coolbox) and four storage times $(T 1=0$ days, $T 2=2$ days, $T 3=4$ days, $T 4=6$ days $)$. Experimental design that is utilized is factorial completely randomized design with three replications. The result showed that package material was not effect to $\mathrm{S}$. johorensis cuttings, while the best storage time was until 0 days, because gave survival rate as 76,11\%. Time storage until 4 days still keep rooting percentage and length of root with each average as $16,67 \%$ and $3.90 \mathrm{~cm}$. For S. smithiana cuttings the best package material was in hardboard up to 0 days, because gave survival rate as $93,33 \%$ and rooting percentage as $22,2 \%$.
\end{abstract}

Keywords: Package material, Storage, Cuttings, S. johorensis, S. SmithianaAbstrak

\begin{abstract}
ABSTRAK
Penelitian pengaruh bahan kemasan dan waktu penyimpanan terhadap persentase berakar stek dua jenis meranti merah (Shorea johorensis dan S. smithiana) telah dilakukan di rumah kaca Balai Penelitian Teknologi Perbenihan Samboja, Kalimantan Timur. Bahan stek Shorea johorensis dan S. smithiana berasal dari permudaan alam di IUPHHK PT Dasa Intiga, Kalimantan Tengah. Tujuan dari penelitian ini untuk mendapatkan jenis bahan kemasan yang tepat serta pengaruh penyimpanan terhadap persentase berakar dua jenis meranti merah. Perlakuan terdiri dari tiga jenis bahan kemasan $(\mathrm{P} 1=$ kardus, $\mathrm{P} 2=$ styrofoam box, $\mathrm{P} 3=$ coolbox $)$ dan empat waktu penyimpanan $(\mathrm{T} 1=0$ hari, $\mathrm{T} 2=2$ hari, $\mathrm{T} 3=4$ hari, $\mathrm{T} 4=6$ hari). Rancangan percobaan yang digunakan adalah faktorial dengan pola acak lengkap dengan ulangan sebanyak tiga kali. Hasil penelitian menunjukkan bahwa bahan kemasan tidak berpengaruh terhadap stek pucuk $S$. johorensis, sedangkan waktu penyimpanan yang terbaik adalah selama 0 hari, karena memberikan persen hidup sebesar 76,11\%. Penyimpanan selama 4 hari masih dapat mempertahankan persen berakar dan panjang akar dengan rataan masing-masing $16,67 \%$ dan $3.90 \mathrm{~cm}$. Untuk stek pucuk $S$. smithiana bahan kemasan yang terbaik adalah kardus tanpa penyimpanan (0 hari), karena memberikan persen hidup sebesar $93,33 \%$ dan persen berakar sebesar $22,2 \%$.
\end{abstract}

Kata kunci : Bahan kemasan, Penyimpanan, Stek, S. johorensis, S. smithiana 


\section{PENDAHULUAN}

\section{A. Latar Belakang}

Dipterocarpaceae merupakan salah satu famili yang mempunyai banyak jenis dan kayunya bernilai ekonomi tinggi. Bahkan beberapa jenis mempunyai pertumbuhan yang cukup cepat seperti Shorea leprosula, $S$. parvifolia, $S$. johorensis, $S$. smithiana, S. macrophylla dan S. platyclados. Pada umur 4,5 tahun rata-rata riap diameter dapat mencapai $1,8-1,9 \mathrm{~cm} /$ th di kawasan Hak Pengusahaan Hutan Sari Bumi Kusuma, Kalimantan Tengah (Soekotjo, 2007, 2008). Oleh karena itu jenisjenis tersebut diprioritaskan untuk ditanam dalam program SILIN (Silvikultur Intensif) dengan sistem Tebang Pilih Tanam Indonesia Intensif (TPTII).

Untuk menunjang keberhasilan kegiatan program SILIN diperlukan ketersediaan bibit yang berkualitas secara berkesinambungan. Upaya untuk pengadaan bibit jenis Dipterocarpaceae secara generatif yang berkesinambungan masih mengalami kendala. Kendala tersebut antara lain periodisitas pembungaan yang tidak teratur (Ashton et al., 1988). Bahkan Yasman dan Smits (1988) melaporkan bahwa jenis Dipterocarpaceae masa musim berbuah massal sekali dalam 4 sampai 13 tahun dengan waktu dorman benih yang sangat singkat hanya beberapa minggu saja (benih recalcitrant). Salah satu alternatif pemecahannya adalah perbanyakan tanaman melalui pembiakan vegetatif dengan stek pucuk. Keuntungan pembiakan vegetatif dengan stek pucuk adalah perbanyakan jenis dapat dihasilkan secara massal, homogen dan dapat digunakan untuk menganalisa kualitas tempat tumbuh (Yasman dan Smits, 1988). Hartman et al. (1990) menyatakan kelebihan perbanyakan vegetatif adalah bibit dapat diproduksi setiap tahun dan mempunyai sifat identik dengan induknya.

Kebutuhan bibit untuk penanaman jenis cepat tumbuh meranti sesuai dengan penyebarannya tidak menjadi masalah, walaupun belum musim berbuah massal masih dapat dilakukan pengadaan bibit dari cabutan. Akan tetapi untuk keperluan penanaman secara ex-situ, akan kesulitan untuk memenuhi kebutuhan bibit tersebut, sehingga perlu dilakukan penelitian teknik pengemasan dan penyimpanan bahan stek pucuk, khususnya meranti yang pertumbuhannya cepat.

Penelitian ini bertujuan untuk mengetahui pengaruh baha kemasan dan lama penyimpanan bahan stek terhadap pertumbuhan stek pucuk 2 jenis meranti yaitu $S$. johorensis dan $S$. smithiana yang ditanam pada program SILIN.

\section{METODE PENGKAJIAN}

\section{A. Lokasi Penelitian}

Lokasi pengambilan bahan stek $S$. johorensis dan S. smithiana dilakukan di PT. Dasa Intiga, Kalimantan Tengah. Secara administratif pemerintahan termasuk dalam Kecamatan Montallat, Kabupaten Barito Utara, Kalimantan Tengah. Pengambilan bahan stek dilakukan dari permudaan alam tingkat semai pada bulan Mei 2008. Pengamatan pertumbuhan stek dilakukan di greenhouse Balai Penelitian Teknologi Perbenihan Samboja pada bulan Mei sampai dengan bulan Agustus 2008.

\section{B. Bahan dan Alat}

Bahan penelitian terdiri dari stek jenis $S$. johorensis dan S. smithiana, koran bekas, media arang sekam, dan air. Pengambilan bahan stek dilakukan dari permudaan alam tingkat semai. Alat penelitian yang akan dipergunakan adalah gunting stek, ember, cool box, styrofoam box, kardus, sigmat, penggaris/mistar, dan alat tulis menulis.

\section{Prosedur Penelitian}

1. Pengambilan Bahan Stek

Bahan stek diambil permudaan alam tingkat semai. Bahan stek dipotong sepanjang \pm $5-10 \mathrm{~cm}$, kemudian diikat berdasarkan jumlah dalam tiap ulangan dan dibungkus dengan koran yang telah dibasahi. Bungkusan ini dikemas dengan tiga jenis kemasan dan disusun terbalik (posisi bagian pangkal stek berada di atas).

2. Pengangkutan, Penyimpanan dan Penanaman Stek

Bahan stek yang telah dikemas diangkut menggunakan angkutan darat dan udara. Waktu pengambilan, pengemasan dan pengangkutan membutuhkan waktu selama 4 hari dan mulai dihitung sebagai $\mathrm{T} 1$.

Penanaman stek dilakukan pada sungkup propagasi KOFFCO dengan media perakaran arang sekam padi. Penanaman dilakukan dalam 4 tahap. Tahap pertama (T1) dilakukan tepat setelah bahan stek sampai dari lapangan. Tahap ke dua dan seterusnya (T2, T3 dan T4) dilakukan setiap selang 2 hari setelah penanaman tahap pertama. 


\section{Pemeliharaan dan Pengamatan}

Penyiraman tanaman dilakukan setiap 2 hari sekali untuk menjaga suhu dan kelembaban. Pengamatan parameter pertumbuhan dilakukan 3 bulan setelah penanaman, yang meliputi persen hidup stek, persen berakar, jumlah akar dan panjang akar.

Persen hidup diperoleh dari persentase stek yang ditanam selama tiga bulan, walaupun belum berakar. Persen berakar diperoleh dari persentase stek yang telah berakar pada akhir pengamatan selama tiga bulan. Jumlah akar dihitung dari jumlah akar yang keluar dari batang stek. Panjang akar diukur dari tumbuhnya akar hingga ujung akar.

\section{Rancangan Percobaan}

Rancangan percobaan yang digunakan adalah Rancangan Acak Lengkap Faktorial 3 x 4 dengan ulangan sebanyak 3 kali untuk masingmasing jenis. Tiap ulangan $S$. johorensis terdiri dari 20 batang stek sehingga jumlah keseluruhan bahan stek yang akan diamati sebanyak $3 \times 4 \times 3 \times$ $20=720$ batang. Sedangkan untuk $S$. smithiana tiap ulangan terdiri dari 15 batang stek sehingga jumlah keseluruhan sebanyak 3 × 4 × 3 x $15=540$ batang. Model linier rancangan percobaan yang digunakan adalah sebagai berikut (Steel dan Torrie, 1960):

$$
\gamma_{\mathrm{ijk}}=\mu+\mathrm{p}_{\mathrm{i}}+\mathrm{t}_{\mathrm{j}}+(\mathrm{pt})_{\mathrm{ij}}+\mathrm{r}_{\mathrm{k}}+\varepsilon_{\mathrm{ijk}}
$$

Dimana: $\gamma_{\mathrm{ijk}}=$ nilai pengamatan pada faktor $\mathrm{P}$ (bahan kemasan) taraf ke-i, faktor $\mathrm{T}$ (penyimpanan) taraf ke-j dan ulangan ke-k;

$\mu=$ rata-rata umum;

$\mathrm{p}_{\mathrm{i}}=$ pengaruh utama dari faktor $\mathrm{P}$ (bahan kemasan) ke-i;

$\mathrm{T}_{\mathrm{j}}=$ pengaruh utama dari faktor $\mathrm{T}$ (penyimpanan) ke-j;

$\mathrm{r}_{\mathrm{k}}=$ pengaruh ulangan ke-k;

eij $=$ komponen acak dari kekeliruan percobaan yang terjadi karena adanya randomisasi perlakuan ke-j pada ulangan ke-i.

Faktor pertama adalah bahan bahan kemasan dan faktor ke dua adalah lama penyimpanan. Perlakuan penelitian adalah sebagai berikut:

Faktor $\mathrm{P}=$ Bahan kemasan, terdiri dari tiga taraf:

$\mathrm{P} 1=$ Kardus

$\mathrm{P} 2=$ Styrofoam box

P3 $=$ Coolbox
Faktor $\mathrm{T}=$ Lama penyimpanan dihitung dari mulai pengambilan, pengemasan dan pengangkutan bahan stek, terdiri dari empat taraf:

$\mathrm{T} 1=0$ hari (tidak disimpan/mulai pengambilan hingga pengangkutan bahan stek)

$\mathrm{T} 2=2$ hari

$\mathrm{T} 3=4$ hari

$\mathrm{T} 4=6$ hari

Catatan: waktu pengambilan hingga pengangkutan bahan stek membutuhkan waktu selama 4 hari

\section{E. Pengolahan dan Analisis Data}

Sebelum data dianalisis, terlebih dahulu dilakukan uji kenormalan untuk data persen hidup dan persen berakar. Apabila penyebaran data tidak normal maka dilakukan transformasi data berdasarkan Tabel Transformasi Arcsin $\checkmark$ persentase (Steel dan Torrie, 1960).

Data yang diperoleh dianalisa dengan uji F (Analisis of Variance). Apabila terdapat perbedaan yang nyata antara perlakuan maupun interaksi kedua faktor tersebut, maka akan dilanjutkan dengan uji beda nyata Tukey.

\section{HASIL DAN PEMBAHASAN}

\section{A. Shorea johorensis}

Data persen hidup dan persen berakar $S$. johorensis tidak menyebar normal, oleh karena itu dilakukan transformasi arcsin $\sqrt{ }$ persentase (Lampiran 1 dan 2). Hasil analisis ragam (Lampiran 3) menunjukkan interaksi antar perlakuan lama penyimpanan dan bahan kemasan tidak memberikan pengaruh nyata, sementara perlakuan lama penyimpanan berpengaruh nyata terhadap persen hidup, persen berakar dan panjang akar stek S. Johorensis.

Untuk mengetahui sejauh mana pengaruh perlakuan tersebut di atas perlu dilakukan uji lanjutan dengan uji beda nyata Tukey. Dari hasil uji beda nyata Tukey terhadap persen hidup, persen berakar, panjang akar dan jumlah daun baru diperoleh nilai $\mathrm{W}_{(0.05)}$ masing-masing sebesar 9,36; 10,57; 2,41 dan 0,68. Gambar 1 menunjukkan perlakuan lama penyimpanan yang paling baik adalah T1 (lama penyimpanan 4 hari) untuk persen hidup dan persen berakar, dengan rataan masing-masing sebesar $76,11 \%$ dan $16,67 \%$. Untuk panjang akar dapat dilakukan penyimpanan hingga T3 (8 hari) dengan rataan sebesar $3,90 \mathrm{~cm}$. 
Hasil analisis ragam yang dilakukan menunjukkan perlakuan pengemasan tidak berpengaruh terhadap parameter yang diamati. Ini menunjukkan selama pengangkutan dan lama penyimpanan tidak terjadi fluktuasi suhu yang tinggi sehingga kondisi suhu dalam masingmasing kemasan tidak jauh berbeda. Hal yang perlu diperhatikan dalam pengemasan dan penyimpanan bahan stek adalah menjaga kondisi suhu dan kelembaban dalam kemasan agar tidak melebihi batas yang dapat ditoleransi oleh bahan tanaman. Pengemasan yang dilakukan tentunya dapat menjaga kelembaban yang tinggi, namun kondisi suhu di dalam kemasan masih banyak dipengaruhi lingkungan di luar kemasan, sehingga tempat penyimpanan, terutama selama pengangkutan, perlu diperhatikan. Hartmann et al. (1990) menyatakan unit penyimpanan untuk stek belum berakar harus dijaga agar kelembaban relatif mendekati 100 persen, patogen harus dikendalikan, dan temperatur harus lebih rendah dari batas ketahanan yang dapat ditoleransi oleh suatu jenis tanpa mengganggu pembentukan akar. Lebih lanjut dikatakan temperatur yang paling baik bagi perakaran untuk hampir semua jenis tanaman adalah $21^{\circ} \mathrm{C}-27^{\circ} \mathrm{C}$ pada siang hari dan $15^{\circ} \mathrm{C}$ pada malam hari. Untuk menjaga suhu agar tidak terlalu tinggi adalah dengan menghindarkan kemasan terkena cahaya matahari langsung dalam waktu yang lama. Dengan memperhatikan efisiensi biaya maka pengemasan dalam kardus yang dilapisi kantong plastik merupakan teknik pengemasan yang paling efisien dibandingkan pengemasan dengan styrofoam box maupun coolbox.

Hasil uji beda nyata Tukey yang dilakukan terhadap perlakuan waktu penyimpanan menunjukkan bahwa waktu penyimpanan yang paling baik adalah penyimpanan selama 4 hari (T1). Artinya semakin lama bahan stek disimpan cenderung menurunkan persen hidup, persen berakar dan jumlah akar. Menurunnya parameter tersebut seperti yang dikemukakan oleh Hartmann et al. (1990) bahwa jangka waktu pengiriman dapat mempengaruhi kualitas akibat penguapan yang berlebihan, kekurangan cahaya, kehilangan kelembaban, serangan pathogen dan/atau pembentukan ethylene. Oleh karena itu bahan stek $S$. johorensis yang diambil harus sesegera mungkin ditanam.

Persentase berakar stek $S$. johorensis lebih rendah dibandingkan persen hidupnya. Ini disebabkan bahan stek memerlukan waktu yang lebih lama untuk membentuk akar. Sakai dan Subiakto (2007) menyatakan bahwa waktu pembentukan akar stek bervariasi tergantung jenis tanamannya. Kesulitan membentuk akar juga dapat dipengaruhi oleh ketebalan dinding sel pada stek. Semakin tebal dinding sel pada stek menyebabkan semakin sulitnya pertumbuhan akar baru (Wright, 1976). Kemampuan membentuk akar juga dipengaruhi oleh perbedaan di dalam individu-individu anakan sumber bahan stek (Hartmann et al., 1990).

Pada akhir pengamatan masih banyak stek $S$. johorensis yang belum membentuk akar, tetapi sudah membentuk tunas baru. Adinugraha dan Setiadi (2003) menyatakan pada umumnya stek bertunas terlebih dahulu sebelum terbentuknya perakaran. Ini disebabkan oleh menurunnya kadar auksin sehingga akan merangsang perkembangan tunas lateral yang selama ini dalam keadaan dorman. Apabila tunas lateral telah tumbuh, selanjutnya akan bersifat sama seperti tunas terminal yaitu menghambat perkembangan tunas-tunas lainnya. Tunas yang baru muncul akan menghasilkan auksin yang akan merangsang pembentukan akar.

Percepatan pembentukan akar $S$. johorensis dapat dilakukan dengan penggunaan zat pengatur tumbuh. Sakai dan Subiakto (2007) melaporkan secara umum pada umur 11 minggu bibit stek jenis-jenis meranti sudah berakar dengan baik dengan menggunakan hormon tumbuh akar. Menurut Priadjati dan Tolkamp (2002) waktu yang diperlukan untuk perakaran adalah 4 - 12 tergantung jenis, umur, sumber bahan stek dan sistem yang digunakan. Omon (2002) melaporkan bahwa stek $S$. leprosula setelah dua minggu ditanam sudah mulai berakar dengan menggunakan hormon tumbuh akar.

Pada waktu pengangkutan dan penyimpanan, terdapat bahan stek yang mengalami stress dan terjadi kerontokan pada daun. Hal ini disebabkan suhu selama pengangkutan yang relatif tinggi, yaitu antara $26-33^{\circ} \mathrm{C}$. Menurut Priadjati dan Tolkamp (2002) faktor penyebab stek menggugurkan daun antara lain terlalu basah di kantung plastik ketika mengumpulkan stek, terlalu panas dalam perjalanan, terlalu lama disimpan sebelum dikerjakan, terkena sinar matahari langsung, mengering atau kepanasan ketika pengumpulan bahan stek dan kekurangan cahaya selama dalam bak stek. Kerontokan daun pada bahan stek berpengaruh terhadap persen hidup stek. Stek $S$. johorensis yang mengalami kerontokan seluruh daun sebelum ditanam tidak ada yang dapat bertahan hidup. 

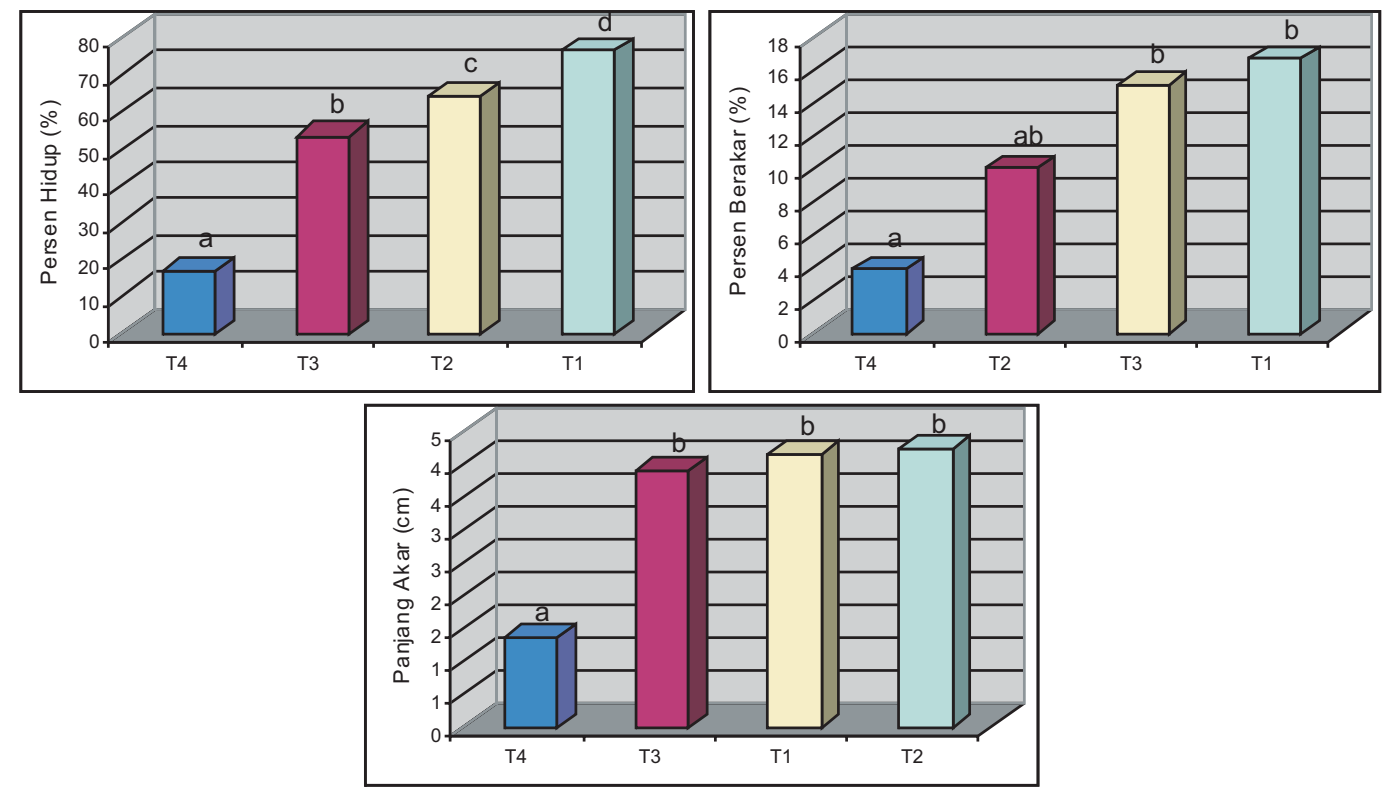

Gambar(Figure) 1. Hasil uji beda nyata Tukey terhadap persen hidup, persen berakar dan panjang akar stek S. johorensis (Result of significant difference Tukey test to survival rate, rooting percentage and length of root of $\mathrm{S}$. johorensis cuttings)

Keterangan (Remarks): Nilai rata-rata yang diikuti oleh huruf yang berbeda menunjukkan perbedaan nyata pada tingkat $5 \%$ berdasarkan uji beda nyata Tukey (Mean values followed by different letters are significantly different at $5 \%$ level based on Tukey significant different test). $\mathrm{P} 1=$ kardus (cardboard box), $\mathrm{P} 2=$ Styrofoam box, $\mathrm{P} 3$ = Cool box; $\mathrm{T} 1$ = empat hari (four day), $\mathrm{T} 2$ = enam hari (six days $), \mathrm{T} 3=$ delapan hari (eight days), $\mathrm{T} 4=$ sepuluh hari (ten days)

\section{B. Shorea smithiana}

Seperti pada $S$. johorensis, data persen hidup dan persen berakar $S$. smithiana tidak menyebar normal, sehingga juga dilakukan transformasi arcsin 1 persentase (Lampiran 4 dan 5). Hasil analisis ragam (Lampiran 6) menunjukkan interaksi perlakuan bahan kemasan dan lama penyimpanan berpengaruh nyata terhadap persen hidup, persen berakar dan jumlah akar stek. Rata-rata persen hidup, persen berakar, jumlah akar dan panajng akar $S$. smithiana ditampilkan dalam Tabel 1 - 4 .

Dari hasil uji beda nyata Tukey terhadap persen hidup, persen berakar, jumlah akar, dan panjang akar diperoleh nilai $\mathrm{W}_{(0.05)}$ masingmasing sebesar 21,$47 ; 24,12 ; 2,42$ dan 2,30. Tabel 1 - 4 menunjukkan untuk persen berakar dapat dilakukan lama penyimpanan hingga 4 hari (T3) dengan rataan sebesar $17,04 \%$, untuk panjang akar dapat disimpan hingga 2 hari (T2), dengan rataan sebesar $3,39 \mathrm{~cm}$. Interaksi perlakuan yang memberikan persen hidup tertinggi adalah bahan kemasan dalam coolbox (P3) selama 0 hari (T1) dengan rataan sebesar 93,33\%. Untuk jumlah akar, interaksi perlakuan yang terbaik adalah pada baha kemasan dalam styrofoam box (P2) selama 2 hari (T2) dengan rataan sebesar 3,42 buah.

Berbeda dengan stek $S$. johorensis, interaksi kedua perlakuan berpengaruh terhadap persen hidup, persen berakar dan jumlah akar stek S. Smithiana. Persen hidup stek S. smithiana yang dikemas dalam kardus dan coolbox lebih tinggi dibandingkan pada styrofoam box. Secara morfologi, kedua jenis ini berbeda. S. smithiana memiliki permukaan yang berbulu kasar dan diameternya besar, berbeda dengan $S$. johorensis yang permukaannya licin dan rata-rata diameternya kecil. Perbedaan morfologi ini diduga mempengaruhi kemampuan adaptasi stek terhadap kondisi lingkungannya.

Persen berakar stek S. smithiana juga lebih kecil dibanding persen hidupnya. Bahan stek yang diambil dari anakan alam menyebabkan perbedaan kemampuan berakar pada masingmasing stek. Stek S. smithiana juga membentuk tunas terlebih dahulu sebelum berakar. Tunas yang terbentuk akan menghasilkan auksin untuk merangsang pembentukan akar. Walaupun tunas telah terbentuk, pada akhir pengamatan terdapat stek yang belum berakar. Aplikasi hormon tumbuh akar dapat mempercepat proses pembentukan akar pada stek S. Smithiana. 
Seperti pada $S$. johorensis, semakin lama disimpan persen hidup stek $S$. smithiana cenderung menurun. Rontok pada daun juga terjadi pada stek $S$. smithiana. Akan tetapi terdapat beberapa bahan stek berdiameter di atas $2 \mathrm{~mm}$ yang dapat bertahan hidup walaupun seluruh daun telah rontok. Hal ini diduga karena diameter batang yang besar sehingga cadangan makanan yang tersedia pada batang stek cukup banyak dan dapat menunjang daya hidup hingga stek membentuk tunas dan akar.

Tabel (Table)1. Rata-rata persen hidup stek S. smithiana (Survival rate average of S. smithiana cuttings)

\begin{tabular}{ccccc}
\hline Bahan Kemasan (Package & \multicolumn{4}{c}{ Lama Penyimpanan (Storage time) } \\
\cline { 2 - 5 } material) & 0 hari (day) & 2 hari (days) & 4 hari (days) & 6 hari (days) \\
\hline Kardus (cardboard box) & $93,33^{\mathrm{f}}$ & $68,89^{\text {cde }}$ & $48,89^{\mathrm{bc}}$ & $22,22^{\mathrm{a}}$ \\
Styrofoam box & $71,11^{\mathrm{de}}$ & $57,78^{\mathrm{bcd}}$ & $44,44^{\mathrm{b}}$ & $15,56^{\mathrm{a}}$ \\
Cool box & $77,78^{\mathrm{de}}$ & $88,89^{\mathrm{ef}}$ & $44,44^{\mathrm{b}}$ & $22,22^{\mathrm{a}}$ \\
\hline
\end{tabular}

Keterangan(Remarks): Nilai rata-rata yang diikuti oleh huruf yang berbeda menunjukkan perbedaan nyata pada tingkat $5 \%$ berdasarkan uji beda nyata Tukey (Mean values followed by different letters are significantly different at $5 \%$ level based on Tukey significant different test)

Tabel(Table) 2. Rata-rata persen berakar stek S. smithiana (Root percentage average of S. smithiana cuttings)

\begin{tabular}{ccccc}
\hline Bahan Kemasan (Package & \multicolumn{4}{c}{ Lama Penyimpanan (Storage time) } \\
\cline { 2 - 5 } material) & 0 hari (day) & 2 hari (days) & 4 hari (days) & 6 hari (days) \\
\hline Kardus (cardboard box) & $22,22^{\mathrm{ab}}$ & $8,89^{\mathrm{ab}}$ & $15,56^{\mathrm{ab}}$ & $0,00^{\mathrm{a}}$ \\
Styrofoam box & $4,44^{\mathrm{ab}}$ & $11,11^{\mathrm{ab}}$ & $24,44^{\mathrm{ab}}$ & $0,00^{\mathrm{ab}}$ \\
Cool box & $17,78^{\mathrm{ab}}$ & $20,00^{\mathrm{ab}}$ & $11,11^{\mathrm{ab}}$ & $4,44^{\mathrm{ab}}$ \\
\hline
\end{tabular}

Keterangan (Remarks): Nilai rata-rata yang diikuti oleh huruf yang berbeda menunjukkan perbedaan nyata pada tingkat $5 \%$ berdasarkan uji beda nyata Tukey (Mean values followed by different letters are significantly different at $5 \%$ level based on Tukey significant different test)

Tabel (Table) 3. Rata-rata jumlah akar stek S. smithiana (Number of root average of S. smithiana cuttings)

\begin{tabular}{ccccc}
\hline Bahan Kemasan (Package & \multicolumn{4}{c}{ Lama Penyimpanan (Storage time) } \\
\cline { 2 - 5 } material) & 0 hari (day) & 2 hari (days) & 4 hari (days) & 6 hari (days) \\
\hline Kardus (cardboard box) & $2,78^{\text {cd }}$ & $1,67^{\text {abcd }}$ & $1,33^{\text {abcd }}$ & $0,00^{\mathrm{a}}$ \\
Styrofoam box & $1,00^{\text {abc }}$ & $3,42^{\mathrm{d}}$ & $2,44^{\mathrm{bcd}}$ & $0,00^{\mathrm{a}}$ \\
Cool box & $1,56^{\mathrm{abcd}}$ & $1,67^{\mathrm{abcd}}$ & $0,83^{\mathrm{abc}}$ & $0,33^{\mathrm{ab}}$ \\
\hline
\end{tabular}

Keterangan(Remarks): Nilai rata-rata yang diikuti oleh huruf yang berbeda menunjukkan perbedaan nyata pada tingkat 5\% berdasarkan uji beda nyata Tukey (Mean values followed by different letters are significantly different at $5 \%$ level based on Tukey significant different test)

Tabel (Table) 4. Rata-rata panjang akar stek S. smithiana (Length of root average of S. smithiana cuttings)

\begin{tabular}{ccccc}
\hline Bahan Kemasan (Package & \multicolumn{4}{c}{ Lama Penyimpanan (Storage time) } \\
\cline { 2 - 5 } material) & 0 hari (day) & 2 hari (days) & 4 hari (days) & 6 hari (days) \\
\hline Kardus (cardboard box) & 3,75 & 2,66 & 1,31 & 0,00 \\
Styrofoam box & 4,07 & 2,79 & 2,79 & 0,00 \\
Cool box & 3,48 & 4,72 & 2,44 & 1,50 \\
\hline Rataan (Average) & $3,76^{\mathrm{c}}$ & $3,39^{\mathrm{c}}$ & $2,18^{\mathrm{b}}$ & $0,50^{\mathrm{a}}$ \\
\hline
\end{tabular}

Keterangan(Remarks): Nilai rata-rata yang diikuti oleh huruf yang berbeda menunjukkan perbedaan nyata pada tingkat 5\% berdasarkan uji beda nyata Tukey (Mean values followed by different letters are significantly different at $5 \%$ level based on Tukey significant different test) 


\section{KESIMPULAN DAN SARAN}

1. Pada S. johorensis perlakuan bahan kemasan tidak berpengaruh terhadap parameter yang diamati. Perlakuan penyimpanan yang paling baik adalah 0 hari untuk persen hidup dan persen berakar, dengan rataan masing-masing sebesar $76,11 \%$ dan $16,67 \%$. Untuk panjang akar dapat dilakukan lama penyimpanan hingga 8 hari dengan rataan sebesar $3,90 \mathrm{~cm}$.

2. Pada S. smithiana perlakuan penyimpanan hingga 8 hari masih dapat mempertahankan persen berakar dengan rataan sebesar 17,04\%, untuk panjang akar dapat disimpan hingga 6 hari, dengan rataan sebesar $3,39 \mathrm{~cm}$. Interaksi perlakuan yang memberikan persen hidup tertinggi adalah pengemasan dalam coolbox selama 3 hari dengan rataan sebesar 93,33\%. Untuk jumlah akar, interaksi perlakuan yang terbaik adalah pada pengemasan dalam styrofoam box selama 6 hari dengan rataan sebesar 3,42 buah.

\section{DAFTAR PUSTAKA}

Adinugraha, H. A. dan D. Setiadi. 2003. Pengaruh Pupuk Organik Cair SNN (Super Natural Nutrition) dan Lamanya Perendaman terhadap Pertumbuhan Stek Pucuk Eucalyptus pellita di Persemaian. Jurnal Pemuliaan Tanaman Hutan 1(2): 49-54. Pusat Penelitian dan Pengembangan Bioteknologi. Yogyakarta.

Ashton, P. M. S., T. J. Givinish, and S. Appanah. 1998. Staggered Flowering in Dipterocarpaceae: New Insight into Floral Induction and the evolution of mast flowering in the seasonal tropic. American Naturalist 132: 44-60.

Hartmann, H. T., D. E. Kester dan F. T. Davies. 1990. Plant Propagation Principles and Practices. Fifth Edition. Prentice-Hall International Inc. Eaglewood Cliffs. New Jersey. 647 pp.
Omon, R. M. 2002. Dipterocarpaceae: Shorea leprosula Miq. Cuttings, Mycorrhizae and Nutrients. Tropenbos-Kalimantan Series 7. MoF-Tropenbos-Kalimantan Project, Indonesia. $144 \mathrm{pp}$.

Priadjati, A. dan G. W. Tolkamp. 2002. Metoda Pembuatan Stek Dipterocarpaceae. dalam: Yasman, I. dan Hernawan editor. Manual Persemaian Dipterocarpaceae. Badan Penelitian dan Pengembangan Departemen Kehutanan. Jakarta. pp. 1-19.

Soekotjo. 2007. Pengalaman dari uji Jenis Dipterocarpa Umur 4,5 Tahun di PT Sari Bumi Kusuma Kalteng. Prosiding Seminar Pengembangan Hutan Tanaman Dipterokarpa dan ekspose TPTII/SILIN, tanggal 4-5 September 2007 di Samarinda. Hlm. 1-16. Balai Besar Penelitian Dipterokarpa. Samarinda.

. 2008. Arah dan Strategi Pengelolaan Hutan Produksi Alam dan Tanaman. Prosiding Seminar Nasional Pengelolaan Hutan Produksi Alami dan Tanaman Prespektif Kebangkitan Sektor Kehutanan, tanggal 16 Oktober 2008 di Samarinda. Hlm. 1-11. Balai Besar Penelitian Dipterokarpa. Samarinda.

Sakai, C. dan A. Subiakto. 2007. Pedoman Pembuatan Stek Jenis-Jenis Dipterocarpaceae dengan KOFFCO System. Pusat Penelitian dan Pengembangan Hutan dan Konservasi Alam. Bogor. 57 pp.

Steel, R. G. D., dan J. H. Torrie. 1995. Prinsip dan Prosedur Statistika: Suatu Pendekatan Biometrik (Terjemahan). PT. Gramedia Pustaka Utama. Jakarta. 772 pp.

Wright, J. W. 1976. Introduction to Forest Genetics. Academic Press. New York. 463 pp.

Yasman, I. dan W. T. M. Smits. 1988. Metode Pembuatan Stek Dipterocarpaceae. Edisi Khusus 03. Balai Penelitian dan Pengembangan Kehutanan Samarinda. Samarinda. $26 \mathrm{pp}$. 
Lampiran(Appendix) 1. Rata-rata persen hidup $S$. johorensis sebelum dan sesudah dilakukan transformasi arcsin $\sqrt{ }$ persentase (Average of survival rate of $\mathrm{S}$. johorensis before and after arcsin $\sqrt{ }$ persentase transformation)

\begin{tabular}{|c|c|c|c|c|c|c|c|c|c|c|c|}
\hline \multirow{3}{*}{$\begin{array}{c}\text { Bahan } \\
\text { kemasan } \\
\text { (Package } \\
\text { Material) }\end{array}$} & \multirow{3}{*}{$\begin{array}{c}\text { Ulangan } \\
\text { (Replications) }\end{array}$} & \multicolumn{4}{|c|}{$\begin{array}{c}\text { Sebelum transformasi } \\
\text { arcsin } \sqrt{\text { persentase }} \\
\text { (before arcsin } \sqrt{\text { persentase }} \\
\text { transformation) }\end{array}$} & & \multicolumn{5}{|c|}{$\begin{array}{l}\text { Setelah transformasi arcsin } \sqrt{ } \text { persentase } \\
\text { (after arcsin } \sqrt{\text { persentase transformation) }}\end{array}$} \\
\hline & & \multicolumn{4}{|c|}{$\begin{array}{c}\text { Lama Penyimpanan } \\
\text { (Storage Time) }\end{array}$} & & \multicolumn{4}{|c|}{$\begin{array}{c}\text { Lama Penyimpanan } \\
\text { (Storage Time) }\end{array}$} & \multirow{2}{*}{$-\frac{2}{3}$} \\
\hline & & है है & $\begin{array}{l}\bar{E} \\
\bar{E}\end{array}$ & है & हे & & $\frac{0}{3}$ & ¿্ & हे हे & है & \\
\hline Kardus & I & 70.00 & 75.00 & 70.00 & 10.00 & 56.25 & 56.79 & 60.00 & 56.79 & 18.44 & 48.01 \\
\hline (cardboard & II & 75.00 & 75.00 & 45.00 & 0.00 & 48.75 & 60.00 & 60.00 & 42.13 & 0.00 & 40.53 \\
\hline \multirow[t]{2}{*}{ box) } & III & 55.00 & 50.00 & 40.00 & 15.00 & 40.00 & 47.87 & 45.00 & 39.23 & 22.79 & 38.72 \\
\hline & Rataan (Average) & 66.67 & 66.67 & 51.67 & 8.33 & 48.33 & 54.89 & 55.00 & 46.05 & 13.74 & 42.42 \\
\hline \multirow[t]{4}{*}{ Styrofoam box } & I & 80.00 & 60.00 & 60.00 & 15.00 & 53.75 & 63.44 & 50.77 & 50.77 & 22.79 & 46.94 \\
\hline & II & 90.00 & 60.00 & 50.00 & 15.00 & 53.75 & 71.56 & 50.77 & 45.00 & 22.79 & 47.53 \\
\hline & III & 90.00 & 70.00 & 65.00 & 5.00 & 57.50 & 71.56 & 56.79 & 53.73 & 12.92 & 48.75 \\
\hline & Rataan (Average) & 86.67 & 63.33 & 58.33 & 11.67 & $\overline{55.00}$ & 68.85 & 52.78 & 49.83 & 19.50 & 47.74 \\
\hline \multirow[t]{4}{*}{ Cool box } & I & 65.00 & 65.00 & 50.00 & 15.00 & 48.75 & 53.73 & 53.73 & 45.00 & 22.79 & 43.81 \\
\hline & II & 70.00 & 55.00 & 55.00 & 40.00 & 55.00 & 56.79 & 47.87 & 47.87 & 39.23 & 47.94 \\
\hline & III & 90.00 & 65.00 & 45.00 & 35.00 & 58.75 & 71.56 & 53.73 & 42.13 & 36.27 & 50.92 \\
\hline & Rataan (Average) & 75.00 & 61.67 & 50.00 & 30.00 & 54.17 & 60.69 & 51.78 & 45.00 & 32.76 & 47.56 \\
\hline \multicolumn{2}{|c|}{ Rataan (Average) } & 76.11 & 63.89 & 53.33 & 16.67 & 52.50 & 61.48 & 53.18 & 46.96 & 22.00 & 45.91 \\
\hline
\end{tabular}


Lampiran(Appendix) 2. Rata-rata persen berakar S. johorensis sebelum dan sesudah dilakukan transformasi arcsin $\sqrt{ }$ persentase (Average of rooting percentage of $\mathrm{S}$. johorensis before and after arcsin $\downarrow$ persentase transformation)

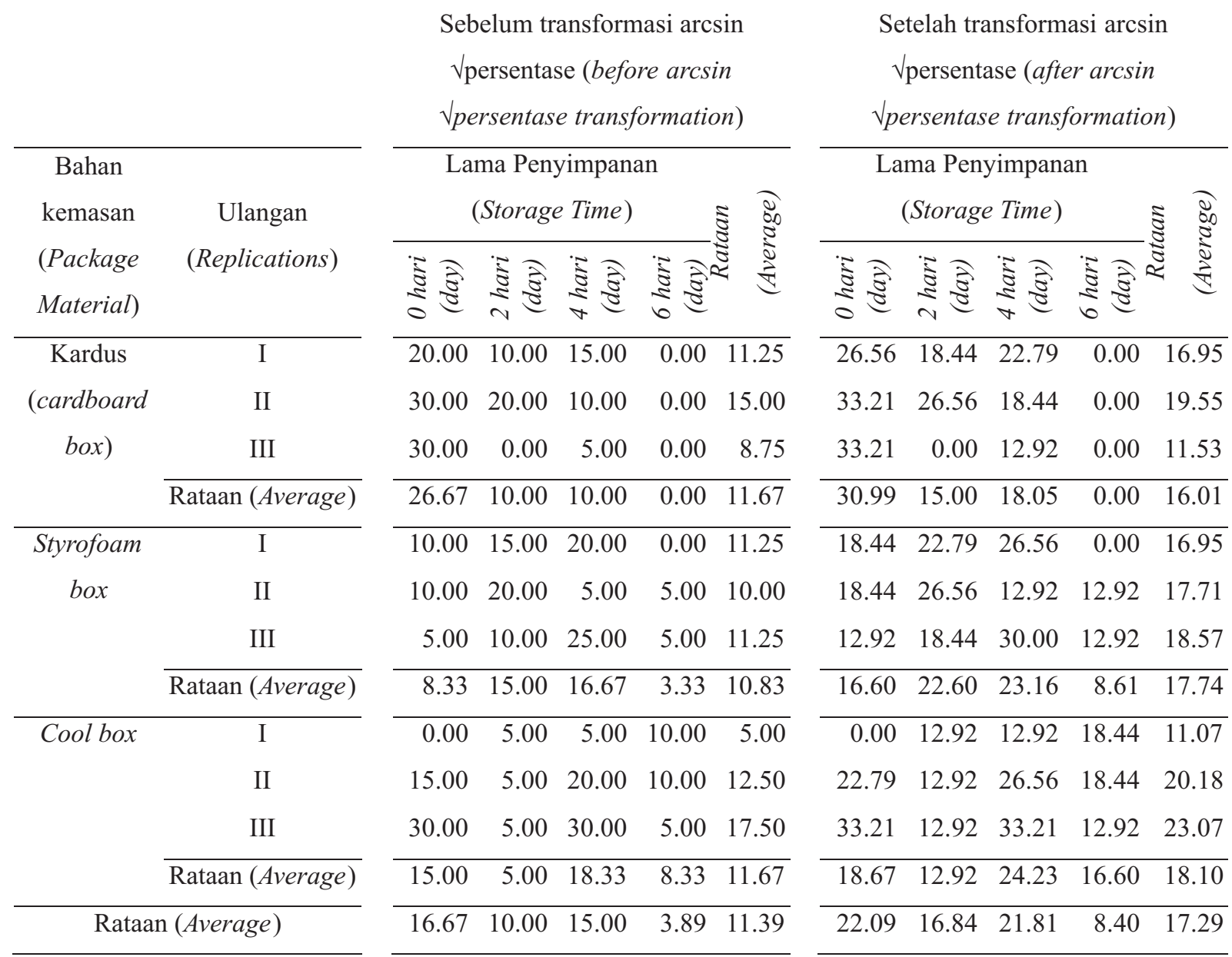


Lampiran (Appendix) 3. Hasil analisis varian untuk S. johorensis (Results of analysis of variance for $\mathrm{S}$. Johorensis)

\begin{tabular}{|c|c|c|c|c|c|}
\hline $\begin{array}{l}\text { Sumber Keragaman } \\
\text { (Source of Variation) }\end{array}$ & $\begin{array}{l}\mathrm{db} \\
(d f)\end{array}$ & $\begin{array}{l}\mathrm{JK} \\
(S S)\end{array}$ & $\begin{array}{c}\mathrm{KT} \\
(M S)\end{array}$ & $\begin{array}{c}\mathrm{F}_{\text {hit }} \\
\left(F_{\text {cal }}\right)\end{array}$ & $\begin{array}{c}\mathrm{F}_{\text {tabel }(0.05)} \\
\left(F_{\text {table }(0.05)}\right)\end{array}$ \\
\hline \multicolumn{6}{|l|}{ Persen Hidup (Survival Rate) } \\
\hline Bahan kemasan (Package Material) & 2 & 218.9882 & 109.4941 & $2.1086^{\mathrm{ns}}$ & 3.40 \\
\hline Lama Penyimpanan (Storage Time) & 3 & 7811.6388 & 2603.8796 & $50.1449^{*}$ & 3.01 \\
\hline Pengemasan x Lama Penyimpanan (Storage Time) & 6 & 702.3085 & 117.0514 & $2.2542^{\mathrm{ns}}$ & 2.51 \\
\hline Galat (Error) & 24 & 1246.2497 & 51.9271 & & \\
\hline Jumlah (Total) & 35 & 9979.1852 & & & \\
\hline \multicolumn{6}{|l|}{ Persen Berakar (Rooting Percentage) } \\
\hline Bahan kemasan (Package Material) & 2 & 30.0461 & 15.0230 & $0.2271^{\mathrm{ns}}$ & 3.40 \\
\hline Lama Penyimpanan (Storage Time) & 3 & 1103.6258 & 367.8753 & $5.5600^{*}$ & 3.01 \\
\hline Pengemasan x Lama Penyimpanan (Storage Time) & 6 & 967.9992 & 161.3332 & $2.4383^{\mathrm{ns}}$ & 2.51 \\
\hline Galat (Error) & 24 & 1587.9637 & 66.1652 & & \\
\hline Jumlah (Total) & 35 & 3689.6347 & & & \\
\hline \multicolumn{6}{|l|}{ Jumlah Akar (Number of Root) } \\
\hline Bahan kemasan (Package Material) & 2 & 0.5691 & 0.2845 & $0.6204^{\mathrm{ns}}$ & 3.40 \\
\hline Lama Penyimpanan (Storage Time) & 3 & 1.8727 & 0.6242 & $1.3609^{\mathrm{ns}}$ & 3.01 \\
\hline Pengemasan x Lama Penyimpanan (Storage Time) & 6 & 5.7207 & 0.9535 & $2.0787^{\mathrm{ns}}$ & 2.51 \\
\hline Galat (Error) & 24 & 11.0083 & 0.4587 & & \\
\hline Jumlah (Total) & 35 & 19.1708 & & & \\
\hline \multicolumn{6}{|l|}{ Panjang Akar (Length of Root) } \\
\hline Bahan kemasan (Package Material) & 2 & 11.0456 & 5.5228 & $1.6054^{\mathrm{ns}}$ & 3.40 \\
\hline Lama Penyimpanan (Storage Time) & 3 & 50.3192 & 16.7731 & $4.8756^{*}$ & 3.01 \\
\hline Pengemasan x Lama Penyimpanan (Storage Time) & 6 & 46.3040 & 7.7173 & $2.2433^{\mathrm{ns}}$ & 2.51 \\
\hline Galat (Error) & 24 & 82.5658 & 3.4402 & & \\
\hline Jumlah (Total) & 35 & 190.2346 & & & \\
\hline
\end{tabular}


Lampiran(Appendix) 4. Rata-rata persen hidup S. smithiana sebelum dan sesudah dilakukan transformasi arcsin $\sqrt{ }$ persentase (Average of survival rate of $\mathrm{S}$. smithiana before and after arcsin $\downarrow$ persentase transformation)

Sebelum transformasi arcsin

$\checkmark$ persentase (before arcsin

$\checkmark$ persentase transformation )

\begin{tabular}{cc}
\hline $\begin{array}{c}\text { Bahan } \\
\text { kemasan } \\
\text { (Package } \\
\text { Material })\end{array}$ & Ulangan \\
(Replications) \\
Kardus \\
(cardboard \\
box $)$
\end{tabular}

Rataan (Average)

\begin{tabular}{|c|c|c|c|c|}
\hline & $\begin{array}{l}\text { ma Penyin } \\
\text { (Storage } 1\end{array}$ & $\begin{array}{l}\text { Impanan } \\
\text { Time) }\end{array}$ & & 8 \\
\hline 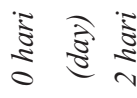 & 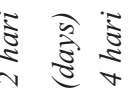 & : & हे & $\approx$ \\
\hline 93.33 & 66.675 & 53.33 & 33.33 & 61.67 \\
\hline 100.00 & 73.33 & 46.67 & 26.67 & 61.67 \\
\hline 86.67 & 66.67 & 46.67 & 6.67 & 51.67 \\
\hline 93.33 & 68.89 & 48.89 & 22.22 & 58.33 \\
\hline 66.67 & 53.33 & 40.00 & 13.33 & 43.33 \\
\hline 73.33 & 66.67 & 33.33 & 20.00 & 48.33 \\
\hline 73.33 & 53.33 & 60.00 & 13.33 & 50.00 \\
\hline 71.11 & 57.78 & 44.44 & 15.56 & 47.22 \\
\hline 66.67 & 86.67 & 26.67 & 6.67 & 46.67 \\
\hline 80.00 & 93.33 & 53.33 & 40.00 & 66.67 \\
\hline 86.67 & 86.675 & 53.33 & 20.00 & 61.67 \\
\hline 77.78 & 88.89 & 44.44 & 22.22 & 58.33 \\
\hline 80.74 & 71.85 & 45.93 & 20.00 & 54.63 \\
\hline
\end{tabular}

Setelah transformasi arcsin $\sqrt{ }$ persentase

(after arcsin $\sqrt{ }$ persentase transformation)

\begin{tabular}{|c|c|c|c|c|}
\hline \multicolumn{4}{|c|}{$\begin{array}{c}\text { Lama Penyimpanan } \\
\text { (Storage Time) }\end{array}$} & \multirow{2}{*}{$-\frac{\mathbb{Z}}{\mathbb{Z}}$} \\
\hline 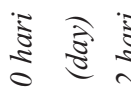 & 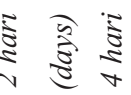 & है & है & \\
\hline 75.00 & 54.76 & 46.89 & 35.24 & 52.97 \\
\hline 90.00 & 58.89 & 43.11 & 31.11 & 55.78 \\
\hline 68.61 & 54.76 & 43.11 & 15.00 & 45.37 \\
\hline 77.87 & 56.14 & 44.37 & 27.12 & 51.37 \\
\hline 54.76 & 46.89 & 39.23 & 21.39 & 40.57 \\
\hline 58.89 & 54.76 & 35.24 & 26.56 & 43.86 \\
\hline 58.89 & 46.89 & 50.77 & 21.39 & 44.49 \\
\hline 57.51 & 49.51 & 41.75 & 23.11 & 42.97 \\
\hline 54.76 & 68.61 & 31.11 & 15.00 & 42.37 \\
\hline 63.44 & 75.00 & 46.89 & 39.23 & 56.14 \\
\hline 68.61 & 68.61 & 46.89 & 26.56 & 52.67 \\
\hline 62.27 & 70.74 & 41.63 & 26.93 & 50.39 \\
\hline 65.88 & 58.80 & 42.58 & 25 . & 48. \\
\hline
\end{tabular}


Lampiran(Appendix) 5. Rata-rata persen berakar S. smithiana sebelum dan sesudah dilakukan transformasi arcsin $\sqrt{ }$ persentase (Average of rooting percentage of $\mathrm{S}$. smithiana before and after arcsin $\downarrow$ persentase transformation)

Sebelum transformasi arcsin $\checkmark$ persentase (before arcsin $\sqrt{\text { persentase }}$ transformation)

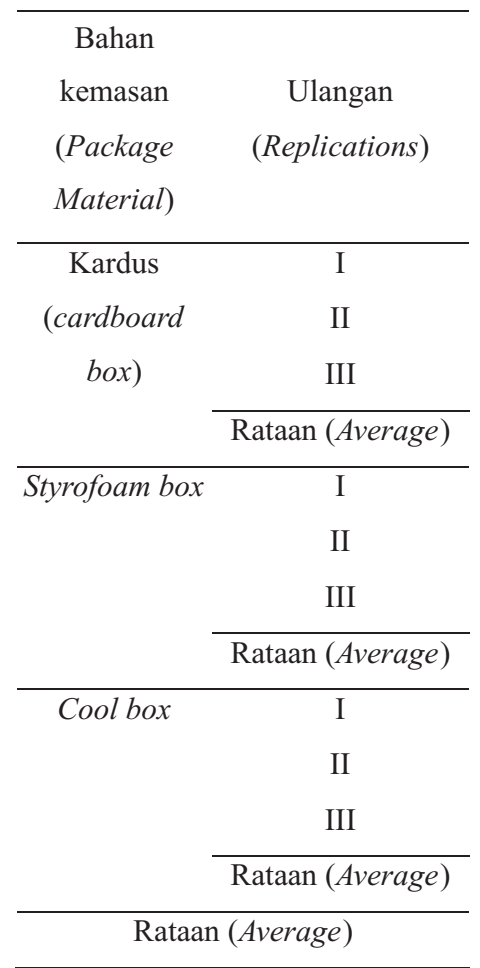

Setelah transformasi arcsin $\sqrt{\text { persentase }}$ (after arcsin $\sqrt{ }$ persentase transformation)

\begin{tabular}{|c|c|c|c|c|}
\hline & $\begin{array}{c}\text { ama Penyin } \\
\text { (Storage }\end{array}$ & Time) & & \\
\hline 吾 & $\begin{array}{l}\bar{\Xi} \\
\text { ¿ } \\
\sim\end{array}$ & 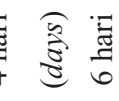 & है & $\tilde{\check{z}}$ \\
\hline 26.56 & 26.56 & 26.56 & 0.00 & 19.92 \\
\hline 31.11 & 0.00 & 26.56 & 0.00 & 14.42 \\
\hline 26.56 & 15.00 & 15.00 & 0.00 & 14.14 \\
\hline 28.08 & 13.85 & 22.71 & .00 & 16.16 \\
\hline 15.00 & 21.39 & 21.39 & 0.00 & 14.45 \\
\hline 0.00 & 21.39 & 26.56 & 0.00 & 11.99 \\
\hline 15.00 & 15.00 & 39.23 & 0.00 & 17.31 \\
\hline 10.00 & 19.26 & 29.06 & 0.00 & 14.58 \\
\hline 26.56 & 26.56 & 0.00 & 0.00 & 13. \\
\hline 2 & 26.56 & 15.00 & 21.39 & 2 \\
\hline 26.56 & 26.56 & 31.11 & 0.00 & 21.06 \\
\hline 24.84 & 26.56 & 15.37 & 7.13 & 18.47 \\
\hline 20.97 & 19.89 & 22.38 & 2.38 & 16.40 \\
\hline
\end{tabular}


Lampiran(Appendix) 6. Hasil analisis varian untuk S. smithiana (Results of analysis of variance for $\mathrm{S}$. Smithiana)

\begin{tabular}{|c|c|c|c|c|c|}
\hline $\begin{array}{l}\text { Sumber Keragaman } \\
\text { (Source of Variation) }\end{array}$ & $\begin{array}{l}\mathrm{db} \\
(d f)\end{array}$ & $\begin{array}{l}\mathrm{JK} \\
(S S)\end{array}$ & $\begin{array}{l}\mathrm{KT} \\
(M S)\end{array}$ & $\begin{array}{l}\mathrm{F}_{\text {hit }} \\
\left(F_{\text {cal }}\right)\end{array}$ & $\begin{array}{c}\mathrm{F}_{\text {tabel }(0.05)} \\
\left(F_{\text {table }(0.05)}\right)\end{array}$ \\
\hline \multicolumn{6}{|l|}{ Persen Hidup (Survival Rate) } \\
\hline Bahan kemasan (Package Material) & 2 & 506.4752 & 253.2376 & $4.7620^{*}$ & 3.40 \\
\hline Lama Penyimpanan (Storage Time) & 3 & 8657.3731 & 2885.7910 & $54.2662^{*}$ & 3.01 \\
\hline Pengemasan x Lama Penyimpanan (Storage Time) & 6 & 926.6334 & 154.4389 & $2.9042^{*}$ & 2.51 \\
\hline Galat (Error) & 24 & 1276.2832 & 53.1785 & & \\
\hline Jumlah (Total) & 35 & 11366.7649 & & & \\
\hline \multicolumn{6}{|l|}{ Persen Berakar (Rooting Percentage) } \\
\hline Bahan kemasan (Package Material) & 2 & 92.0701 & 46.0351 & $0.6861^{\mathrm{ns}}$ & 3.40 \\
\hline Lama Penyimpanan (Storage Time) & 3 & 2389.3544 & 796.4515 & $11.8706^{*}$ & 3.01 \\
\hline Pengemasan x Lama Penyimpanan (Storage Time) & 6 & 1092.5829 & 182.0971 & $2.7140^{*}$ & 2.51 \\
\hline Galat (Error) & 24 & 1610.2711 & 67.0946 & & \\
\hline Jumlah (Total) & 35 & 5184.2785 & & & \\
\hline \multicolumn{6}{|l|}{ Jumlah Akar (Number of Root) } \\
\hline Bahan kemasan (Package Material) & 2 & 2.3036 & 1.1518 & $1.7055^{\text {ns }}$ & 3.40 \\
\hline Lama Penyimpanan (Storage Time) & 3 & 22.8941 & 7.6314 & $11.2999^{*}$ & 3.01 \\
\hline Pengemasan x Lama Penyimpanan (Storage Time) & 6 & 13.0868 & 2.1811 & $3.2296^{*}$ & 2.51 \\
\hline Galat (Error) & 24 & 16.2083 & 0.6753 & & \\
\hline Jumlah (Total) & 35 & 54.4929 & & & \\
\hline \multicolumn{6}{|l|}{ Panjang Akar (Length of Root) } \\
\hline Bahan kemasan (Package Material) & 2 & 7.3825 & 3.6912 & $1.1797^{\mathrm{ns}}$ & 3.40 \\
\hline Lama Penyimpanan (Storage Time) & 3 & 58.3810 & 19.4603 & $6.2197^{*}$ & 3.01 \\
\hline Pengemasan x Lama Penyimpanan (Storage Time) & 6 & 9.2379 & 1.5397 & $0.4921^{\mathrm{ns}}$ & 2.51 \\
\hline Galat (Error) & 24 & 75.0920 & 3.1288 & & \\
\hline Jumlah (Total) & 35 & 150.0935 & & & \\
\hline
\end{tabular}

